\title{
The Development and Application of Interactive Multimedia in Project-Based Learning to Enhance Students' Achievement for 2D Animation Making
}

\author{
https://doi.org/10.3991/ijet.v15i16.16521 \\ Rahmania Sri Untari ( $\left.{ }^{\bowtie}\right)$, Waras Kamdi, Ahmad Dardiri, \\ Syamsul Hadi, Didik Nurhadi \\ Universitas Negeri Malang, Malang, Indonesia \\ rahmania.sriuntari2020@gmail.com
}

\begin{abstract}
Enhancing the quality of student competencies effectively cannot be separated from the development of learning resources through technological innovation. Interactive multimedia is an innovative learning resource that can be integrated with Project-Based Learning, which is a solution to the problems that occur for 2D Animation Making. The purpose of this study is to develop interactive multimedia and assess the effectiveness of its application in ProjectBased Learning $(\mathrm{PjBL})$ for $2 \mathrm{D}$ animation making. The researchers applied the Research and Development method using the 4D model. This study was conducted at the Universitas Muhammadiyah Sidoarjo, with a total of 66 students of Information Technology Education. Based on the results of the study, validation by material and media experts showed that interactive multimedia learning media is excellent and feasible to use. The effectiveness of the application of interactive multimedia in $\mathrm{PjBL}$ has a significant positive effect on learning achievement for making $2 \mathrm{D}$ animations.
\end{abstract}

Keywords-Interactive multimedia, learning achievement, 2D Animation.

\section{$1 \quad$ Introduction}

The 4.0 era requires educators to be able to adjust information development very quickly by making learning more relevant [1]. Interactive multimedia with various roles is an essential technological science [2]. For instance, it makes learning media more exciting and interactive and enhances the quality and the process of teaching and learning, which can be done anywhere and anytime [3]. Multimedia animation material can be presented in the form of two or three-dimensional images, interactive text display, animated effects, attractive color combinations, and audio aids that help students understand the material more easily [4]. Therefore, interactive multimediabased learning is needed to develop students' competencies efficiently and effectively.

Information Technology Education students at the tertiary level must have the ability to make 2D animations [5]. However, several previous studies have shown that student learning outcomes for making $2 \mathrm{D}$ animations are still relatively low. This is 
because there are still misconceptions and misunderstandings [6],[7]. Students experience confusion in integrating learning resources in class with 2D animations [8].

In integrating the use of interactive multimedia and 2D animation making, it takes a learning process that presents a problem on a project-based basis. This learning model is known as Project-Based Learning (PjBL) [9]. However, this model needs to be studied further. Research on this model is focused on scenario design that needs to be well designed [10]. Problems raised by teachers are often applicable in the real world, and therefore, students are trained to solve problems that require creative thinking [11],[12]. PjBL presents challenges that require students to work together in groups to solve problems to arouse their curiosity and initiative in problem-solving [13].

Apart from its complex technology, the problem faced by logic is that it is getting extensive and needing a perfect analysis structure. This means that logical thinking in learning is essential, especially in solving mathematical problems [14], [15], [16]. Logical thinking ability helps students to think rationally, critically, straightly, precisely, orderly, methodically, and coherently. They also increase the ability to think abstractly, carefully, and objectively. Importantly, the logic increases intelligence and the ability to think sharply and independently to increase love for truth and avoid mistakes and errors [17],[18].

Based on an initial preliminary study on Information Technology Education at Universitas Muhammadiyah Sidoarjo, students were accustomed to technology products through the implementation of PjBL. The problem was that the students had never received a project to make $2 \mathrm{D}$ animation by involving learning innovations in the form of interactive multimedia use. Research with an "apple to apple" comparison framework, which compares two variations of the PjBL model or scenario, is needed in Information Technology Education to get more targeted research results [19].

Based on the gap analysis above, students need interactive multimedia on PjBL to enhance students' achievements for 2D Animation Making. Besides, a review of logical thinking skills is required to determine the enhancement of students' achievement for 2D Animation Making to test the level of success of the application of interactive multimedia. Therefore, researchers formulated the research objectives as follows: 1) To develop interactive multimedia in learning for 2D Animation Making; 2) To assess the effectiveness of the use of interactive multimedia in the application of PjBL by reviewing differences in students' logical thinking abilities.

\section{$2 \quad$ Method}

This research applied Research and Development (R\&D) with a 4D model by Thiagarajan [20]. Researchers used two main stages with the development of interactive multimedia on the first stage and a quasi-experimental design to assess the effectiveness of interactive multimedia on the second stage. In the first stage, the development model used was the 4D with four main steps, namely, Define, Design, Development, and Disseminate. 
The flow of the interactive multimedia development using the 4D model are as follows: 1) Define; this stage aimed to analyze the needs in the learning process and collect various kinds of information related to the product to be developed; 2) Design; this stage aimed to create a design of learning media that can be used in multimedia animation lectures; 3) Development; this stage aimed to produce development products in the form of interactive multimedia. At this stage, the researcher also conducted expert validation (material and media expert followed by revision) and testing the product with a $2 \times 2$ factor pattern design; 4) Disseminate; this was the final stage of development with the 4D model. This stage is carried out with interactive multimedia socialization through distribution to lecturers and students. However, this study is limited to the Development stage, this is done to get interactive multimedia that is truly valid and feasible to use, before it is used by lecturers and students of Information Technology Education in the wider population.

Table 1. Experimental design of $2 \times 2$ factorial design patterns

\begin{tabular}{|l|l|l|}
\hline \multirow{2}{*}{\multicolumn{1}{|c|}{ Logical Thinking Ability }} & \multicolumn{2}{|c|}{ Treatment } \\
\cline { 2 - 3 } & Interactive Multimedia - PjBL $\left(\mathrm{A}_{1}\right)$ & $\mathrm{PjBL}\left(\mathrm{A}_{2}\right)$ \\
\hline High $\left(\mathrm{B}_{1}\right)$ & $\mathrm{A}_{1} \mathrm{~B}_{1}$ & $\mathrm{~A}_{2} \mathrm{~B}_{1}$ \\
\hline Low $\left(\mathrm{B}_{2}\right)$ & $\mathrm{A}_{1} \mathrm{~B}_{2}$ & $\mathrm{~A}_{2} \mathrm{~B}_{2}$ \\
\hline
\end{tabular}

The second stage was the quasi-experiment. The study design used the $2 \times 2$ factorial design patterns [21]. As seen in Table 1, A1 is the group used interactive multimedia with $\mathrm{PjBL}$ and $\mathrm{A} 2$ is the group used $\mathrm{PjBL}$ only. $\mathrm{B} 1$ is a group of students who have high logical thinking abilities, B2 is a group of students who have low logical thinking abilities. Thus, there are four groups namely the A1B1 group is the group used interactive multimedia with PjBL with high logical thinking skills, the A1B2 group is the group used interactive multimedia with $\mathrm{PjBL}$ with low logical thinking skills, A2B1 is the group used PjBL with high logical thinking abilities, and A2B2 is the group uses PjBL with low logical thinking abilities.

\subsection{Participants}

This study involved students of Information Technology Education, Universitas Muhammadiyah Sidoarjo in Semester 5, 2020-2021 academic year. There were two class participants assigned to be the control and experiment groups, with 32 and 34 students from class A1 and class A2 respectively.

\subsection{Data collection tool}

The Data Collection Tool consists of three instruments, namely, a media validation questionnaire, a logical thinking test, and a learning achievement test. The instrument questionnaire for media validation includes display and language, presentation of images / graphics and animation, and multimedia principles. This instrument is used to obtain data on validator ratings and opinions on interactive media compiled and an assessment of the suitability of the material with interactive media. Data obtained 
from the media validation questionnaire were qualitative and quantitative data. Thus, this instrument can act as a guide and reference in revising interactive media. Material validation consists of the appropriateness of the contents of the material, the accuracy and completeness of the material, the suitability of the Acting Board.

To measure logical thinking ability used Piagetian objective formal, which is a type of objective test that has been developed as an instrument to measure the ability of formal thinking. This test was adopted from Ardhana [22]. Consisting of 24 items, the indicators for evaluating logical thinking ability consist of the following 3 indicators, namely: 1) thoughtfulness, 2) ability to reason, and 3) drawing conclusions.

To measure learning outcomes, it is obtained from written tests and observation rubrics with pretest and posttest. The assessment rubric of observation involves planning, processes, products, presentations, and portfolios. The checklist for performance observation rubrics starts from designing the design, making presentations, and group work activities. The test instrument consisting of 40 questions was tested using item validity through the analysis of question items previously tested using the Bivariate Pearson correlation method (Pearson's Moment Product).

\subsection{Data analysis technique}

The data were analyzed through descriptive and inferential analysis [23]. Descriptive analysis was used to analyze data from product validation results by material and media experts, while inferential analysis tests the hypotheses. The SPSS version 22 program tested the hypothesis with a significance value of $0.05(5 \%)$. Interpretation of product assessment results followed the assessment criteria on a scale of 5, such as: 1) is very good; 2) good; 3) enough; 4) lacking; and 5) very lacking [24].

A hypothesis test was carried out with an ANOVA analysis to determine the effectiveness of the product. $\mathrm{H} 0$ was rejected because the sig value was less than 0.05 , which means the combination of Interactive multimedia with $\mathrm{PjBL}$ had a significant impact on student achievement for making 2D text animation.

\section{Results and Discussion}

The process of developing interactive multimedia followed the Define, Design, Development and Disseminate stages, which are explained as follows.

\subsection{Define stage}

Define stage was carried out in several steps, starting from needs analysis, determining the scope of material, collecting references, and determining the limits [25]. It is necessary to develop learning media in the form of interactive multimedia, especially in animation-based learning courses that enhance the achievements for making 2D animation. The materials, references, and the limits to be developed are based on the curriculum of the study program. 
Material for developing interactive multimedia in PjBL learning consists of some software such as MS Word as a place to write learning material, CorelDraw as a platform for designing components in an application, visual studio code as developing applications in native code (in the form of machine language running above Windows), and managed code (in the form of Microsoft Intermediate Language above the .NET Framework), and Adobe Flash as an interactive menu, interactive form, and learning server screen media. This interactive multimedia is designed to provide learning material based on PjBL through eight features. These eight features have project-based properties that consist of course descriptions, basic theory and animation, text animation and action scripts, images and audio, slideshows and presentations, animation projects, help, and about me.

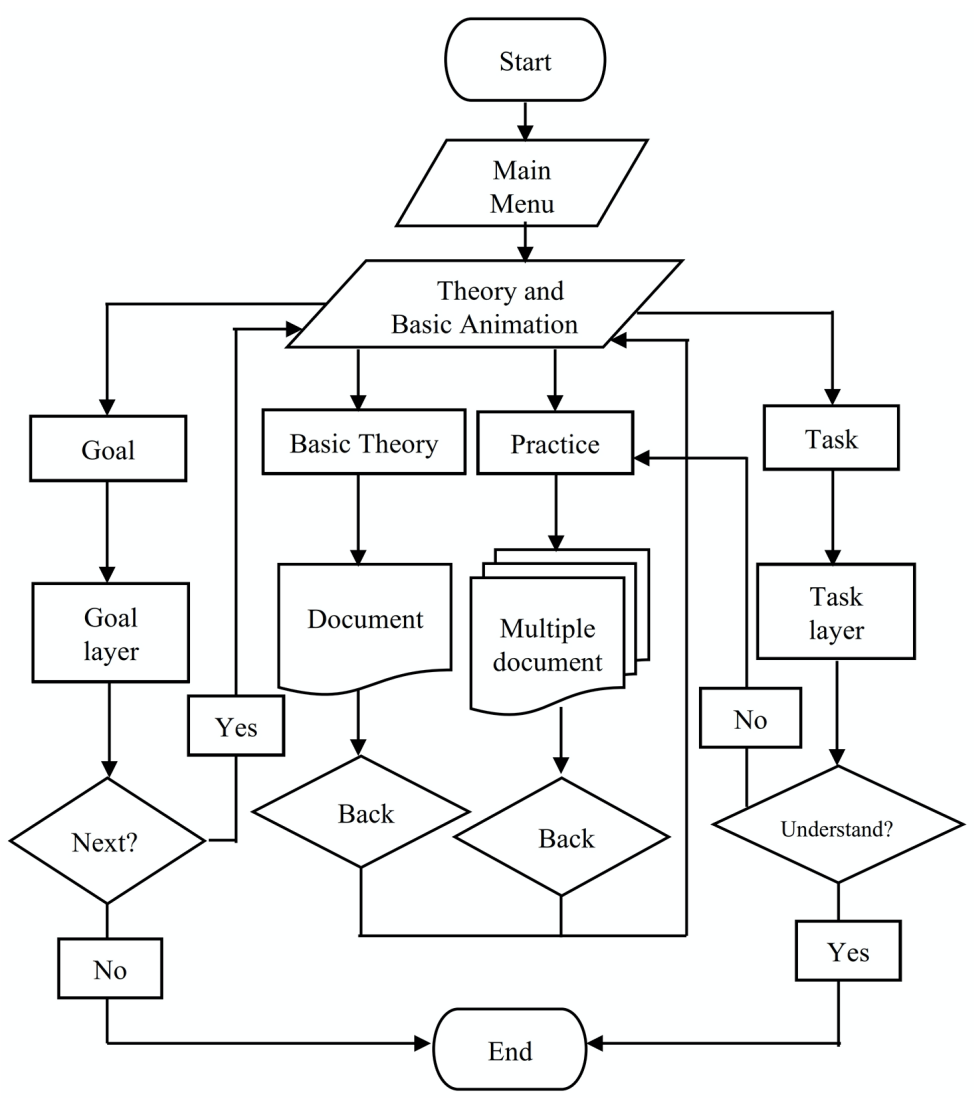

Fig. 1. Interactive Multimedia Flowchart

The algorithmic process involved in designing eight interactive multimedia features on the main menu is shown by the user flowchart (See Figure 1). One such feature is the "Basic Theory and Animation" which consists of Objectives, Basic Theory, Exercises, and Tasks. The exercise and assignment sub-features indicate that interac- 
tive multimedia is integrated with the PjBL application, so that the ability of students for making $2 \mathrm{D}$ animations can be enhanced.

\subsection{Design stage}

Design stages were carried out to design interactive multimedia, including learning resources in the form of textbooks [26]. It started with designing the achievements of the course, the expected final ability, and the subject material by including images, text, animation, audio, and video. The process of compiling the book was carried out using several computer programs, including Ms. Office Word, Corel Draw, and Adobe Flash.

The stage for designing interactive multimedia included several stages; the first step was to create designs for application icons and images using Corel Draw. The next step was to design the interface using Adobe Flash, such as creating icons and animated movement of icons through the arrangement in Adobe Flash. Figure 2 shows the stages when creating content using timeline, frames, and coding to design learning media. This section was the most complicated part because they had to design one by one, starting from inserting objects, images, text, audio, video, background, making animated moves, making interactive buttons in great detail. If the process was not followed step by step, the animation would not be successfully created. This process might be complicated if there were any mistakes in language and logic.

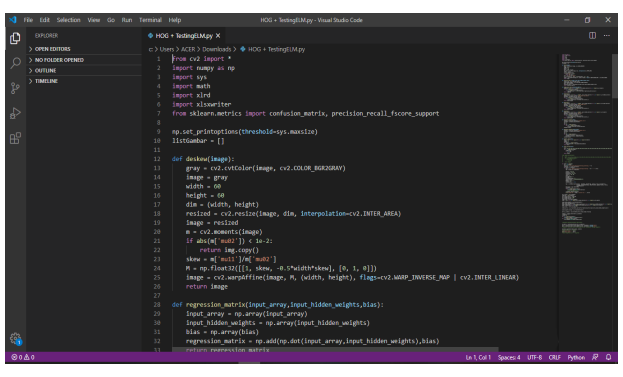

(a) The Coding Process in the Visual Studio Code Interface

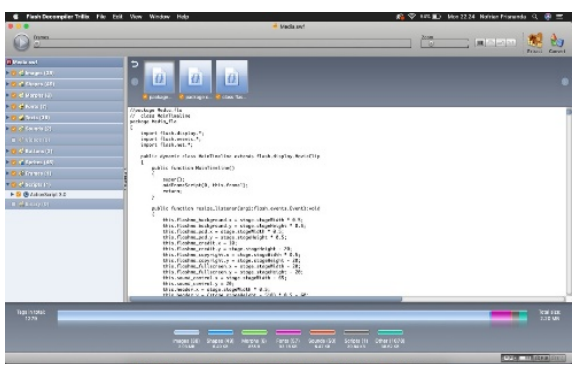

(b) The Visual Studio Running Coding process to Adobe Flash

Fig. 2.

Before building an application, it took writing features in the app through visual studio code with the ActionScript 3.0 programming language shown in Figure 2 (a). After writing the coding in the visual studio code, it ran the coding in Adobe Flash shown in Figure 2 (b). Running the coding was useful to facilitate the process of rendering interactive multimedia on Adobe Flash or Macromedia Flash. 


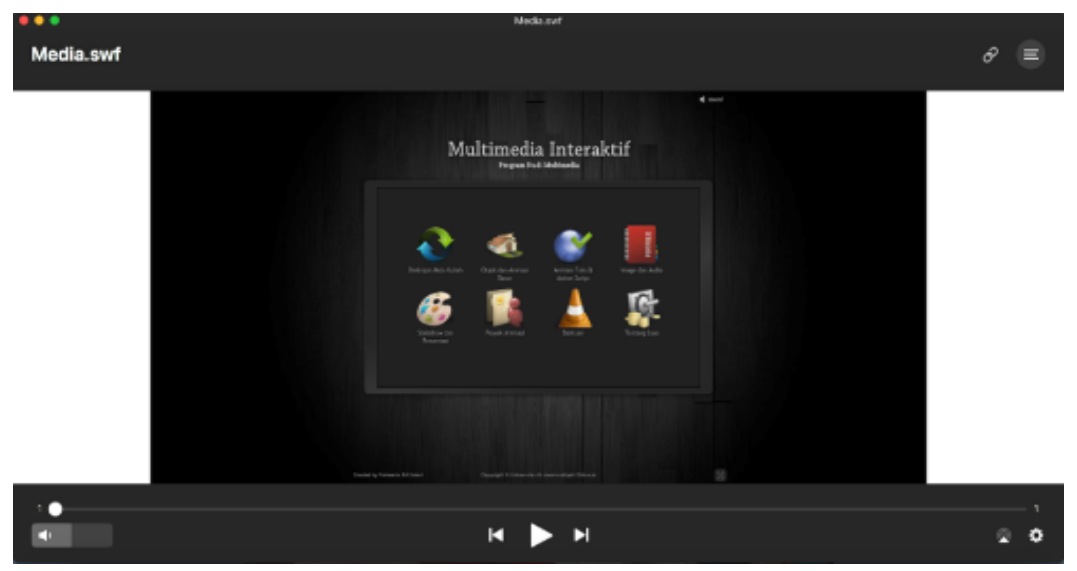

Fig. 3. The Front-Page interface of Interactive Multimedia

Figure 3 showed an interactive multimedia learning display. The learning media is often more interesting and interactive because of the effects of animation on each material presented. Furthermore, it is also equipped with an image or graphic content, audio and video that supports the delivery of material, and therefore, it is easy to understand. Also, the readers understand the material because it is equipped with a guide / instruction and several navigation buttons.

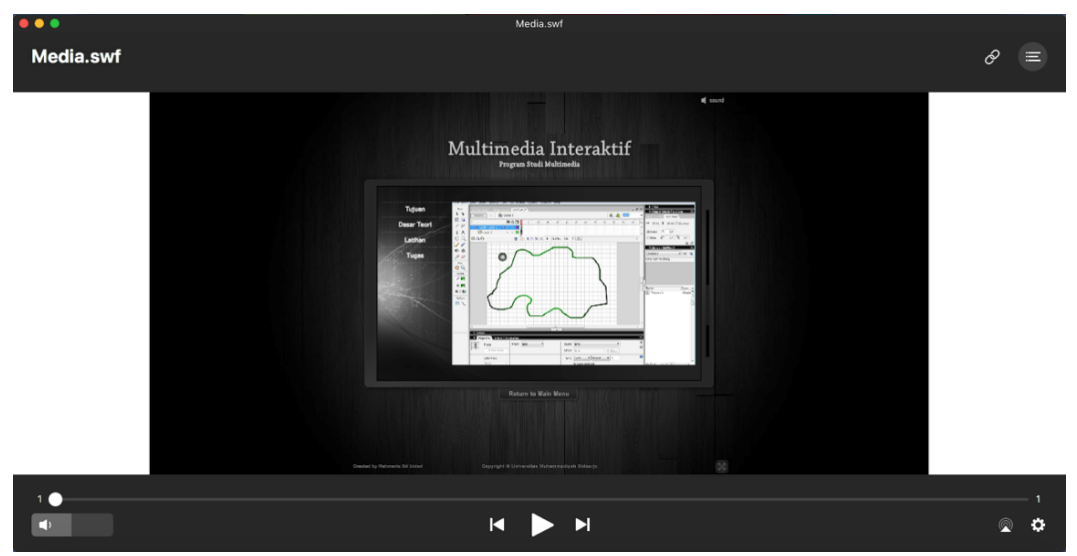

Fig. 4. Exercise Sub-Feature Making 2D Animation

The interactive multimedia is equipped with sub-features of making 2D animation exercises to help students make 2D animation easier (See Figure 4). In this subfeature, students are trained to make 2D animation through Adobe Flash. In addition, there are guided motion tween. The purpose of this guided motion tween is to create an animated path with a moving object. 


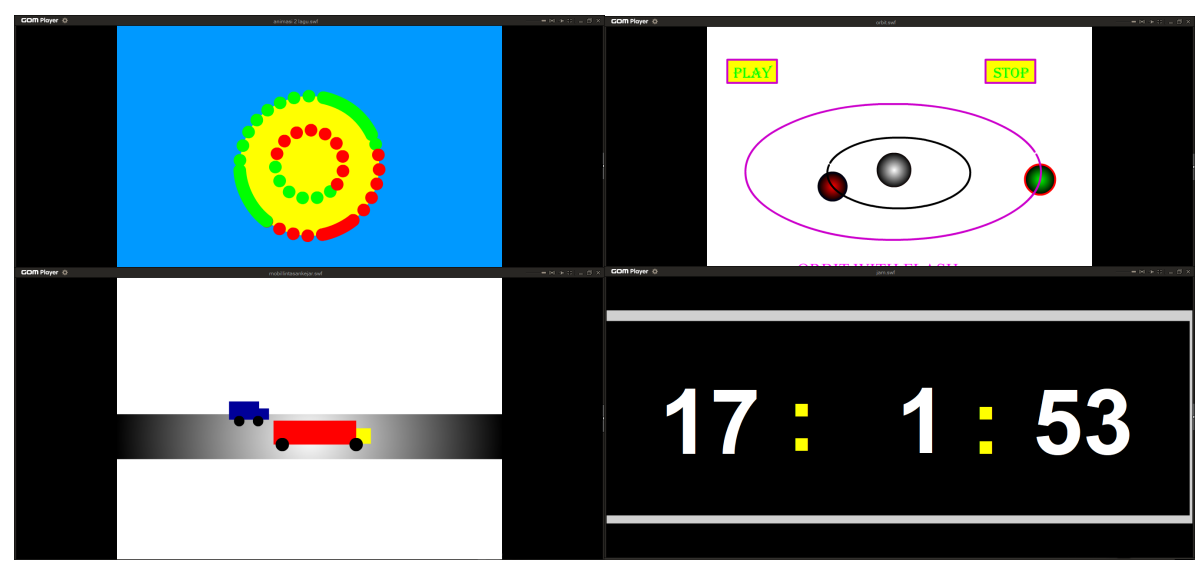

Fig. 5. Project for 2D Animation Making

In the task feature, there are projects provided. Figure 5 showed four examples of projects for making 2D animation, namely: a) making a moving car made of rectangles and circles that run straight, b) making the orbit of the solar system around the sun, c) making an animation of 2 circles that rotate in opposite directions, d ) create animated digital clocks.

\subsection{Development stage}

The product validity test is carried out with a questionnaire given to material and media experts to assess the suitability of the product. The results of the assessment by experts are shown in Table 2.

Table 2. The Results of Expert Validation

\begin{tabular}{|c|l|c|}
\hline \multicolumn{1}{|c|}{ Validator } & \multicolumn{1}{|c|}{ Indicator } & Score \\
\hline \multirow{4}{*}{ Material Expert } & 4.5 \\
\cline { 2 - 3 } & Content Suitability & 4.4 \\
\cline { 2 - 3 } & Accuracy and completeness of the material & 4.4 \\
\hline \multirow{2}{*}{ Average } & Suitability with the Student-Centered Learning method & 4.43 \\
\hline \multirow{3}{*}{ Media Expert } & Layout and language & 4.2 \\
\cline { 2 - 3 } & Presentation of pictures/graphics and animation & 4.5 \\
\cline { 2 - 3 } & The principle of multimedia & 4.2 \\
\hline Average & 4.3 \\
\hline
\end{tabular}

Table 2 is the result of product validity testing by material and media experts. The average score was 4.43 , which is included in the excellent category. Furthermore, validation by media experts gives an average rating of 4.3 , which is also in the excellent category. The experts agree that this multimedia presents $2 \mathrm{D}$ animation material content that is quite complete, acceptable, and suitable for learning activities. 
The effectiveness test on the combination of Interactive multimedia with PjBL was carried out with two groups of students, including control and experimentation. The experiment was conducted using two ways Anova, which aimed to determine the effect of Interactive multimedia with $\mathrm{PjBL}$ on the ability to make 2D animation [19]. Figure 3 shows the students' achievements for making 2D animations. The students were randomly selected and divided into control and experimental groups with 32 and 34 participants, respectively.

The statistical description of learning achievement between groups of students taught with PjBL interactive multimedia and a combination of PjBL without considering the level of logical thinking ability is presented in Table 3.

Table 3. Statistics of Learning Achievement based on the Treatment Groups

\begin{tabular}{|l|c|c|}
\hline \multirow{2}{*}{\multicolumn{1}{|c|}{ Parameter }} & \multicolumn{2}{|c|}{ Treatment Groups } \\
\cline { 2 - 3 } & Interactive Multimedia - PjBL & PjBL \\
\hline N & 32 & 34 \\
Highest score & 96 & 93 \\
Lowest score & 80 & 72 \\
Average & 87,29 & 83,76 \\
Std Deviation & 3,88 & 5,52 \\
\hline
\end{tabular}

Based on Table 3, the overall average of students learning achievement in the PjBL group with interactive multimedia is 87.29 and higher than in the $\mathrm{PjBL}$ group of 83.76 .

Table 4. The Statistics of Learning Achievement Based on the Level of Logical Thinking Ability

\begin{tabular}{|c|l|c|c|c|}
\hline \multicolumn{1}{|c|}{ Treatment } & LTA & Mean & Std. Deviation & N \\
\hline \multirow{4}{*}{ Interactive Multimedia -PjBL } & Low & 87,31 & 3,281 & 16 \\
\cline { 2 - 5 } & High & 87,62 & 4,425 & 16 \\
\cline { 2 - 5 } & Total & 87,47 & 3,835 & 32 \\
\hline \multirow{3}{*}{ PjBL } & Low & 86,24 & 4,562 & 17 \\
\cline { 2 - 5 } & High & 81,53 & 5,625 & 17 \\
\cline { 2 - 5 } Total & Total & 83,88 & 5,580 & 34 \\
\hline \multirow{3}{*}{} & Low & 86,76 & 3,969 & 33 \\
\cline { 2 - 5 } & High & 84,48 & 5,880 & 66 \\
\cline { 2 - 5 } & Total & 85,62 & 5,107 & 33 \\
\hline
\end{tabular}

Table 4 showed that in the experimental group, students with higher logical thinking ability have higher learning achievement. In the control group, students with low logical thinking skills have higher learning achievement. The summary results of the analysis of variance at the treatment source are presented in Table 5. 
Table 5. The Results of Treatment Analysis with Learning Achievement

\begin{tabular}{|l|c|c|c|c|c|}
\hline \multicolumn{1}{|c|}{ Source } & $\begin{array}{c}\text { Type III Sum of } \\
\text { Squares }\end{array}$ & df & Mean Square & F & Sig. \\
\hline Corrected Model & $401,049^{\mathrm{a}}$ & 3 & 133,683 & 6,403 &, 001 \\
\hline Intercept & 484014,941 & 1 & 484014,941 & 23182,196 &, 000 \\
\hline Treatment & 212,032 & 1 & 212,032 & 10,155 &, 002 \\
\hline LTA & 79,547 & 1 & 79,547 & 3,810 &, 047 \\
\hline Treatment *LTA & 103,789 & 1 & 103,789 & 4,971 &, 029 \\
\hline Error & 1294,482 & 62 & 20,879 & & \\
\hline Total & 485541,000 & 66 & & & \\
\hline Corrected Total & 1695,530 & 65 & & & \\
\hline
\end{tabular}

Table 5 showed the source of "treatment" with degree of freedom (df) = 1; value of $\mathrm{F}=10.155$ with $\mathrm{Sig}=0.002$. The magnitude of the probability/significance is less than $0.05,(p \leq 0.05)$ and therefore H0 is rejected. Since $0.002<0.05$, there is a significant difference in $2 \mathrm{D}$ animation learning achievement between groups of students taught Interactive multimedia with $\mathrm{PjBL}$ and those with a PjBL combination. The average of learning achievement on groups of students taught Interactive multimedia with PjBL is significantly different as shown in Table 6.

Table 6. Summary of the Average Learning Achievement

\begin{tabular}{|l|c|c|c|}
\hline \multicolumn{1}{|c|}{ Treatment group } & Average & Sd & N \\
\hline Interactive Multimedia - PjBL & 87,293 & 3,885 & 32 \\
\hline PJBL & 83,761 & 5,522 & 34 \\
\hline
\end{tabular}

In Table 6, the average student achievement in the interactive multimedia group with $\mathrm{PjBL}$, without logical thinking ability, is higher than in the PjBL group. Therefore, the treatment gave a significant effect on learning achievement for making $2 \mathrm{D}$ animation. Based on the results of the study, students absorb $70 \%$ of what is carried out practically and $50 \%$ of what is heard and seen. Additionally, teaching and learning activities can be more effective and easier in case they are supplemented with facilities because $83 \%$ of learning through the sense of sight is easily remembered [27].

Based on the validity and effectiveness test of the product, interactive multimedia in $\mathrm{PjBL}$ has a significant effect on learning achievement for making $2 \mathrm{D}$ animations and can be used in lectures. Therefore, interactive multimedia learning media can be distributed and used for broader class groups, especially in the Information Technology Education Engineering program.

\subsection{Discussion}

The result of the development of interactive multimedia in this study is a learning system, which uses software and hardware, which functions to simplify the process of data in the form of images, videos, photography, graphics, and animation, in collaboration with sound, text, and voice data that are controlled interactively by computer [28]. Through interactive multimedia products, students can arrange coordination for 
making products through projects easily. Therefore, multimedia animation plays an important role in education [29].

Project-based multimedia learning is a combination of project-based learning and interactive multimedia. This combination represents a strong teaching strategy. Project-based multimedia learning is a teaching method that allows students to acquire new knowledge and skills in the process of designing, planning, and producing multimedia products [30]. This learning provides activities for students from contentbased to problem-based to provide a realistic learning approach and create education that emphasizes real-world challenges and logical thinking skills through problembased learning by making a 2D animation project [31]. By using interactive multimedia, students can use their knowledge to become more meaningful learning through a project to make products.

Through project-based learning that invites students to make a project-based product. Elements in this 2D animation product can be converted into digital forms and adjusted for the final project, so that student learning outcomes can be enhanced. The results showed that students utilized their logical thinking skills to use interactive multimedia and collaborate cooperatively with their groups, respectively. Students are also more enthusiastic and interested in the learning process in class. Students can make 2D animations from Macromedia Flash and enjoy the atmosphere of learning in class, so they participate in doing assignments individually or in groups. Thus, students build knowledge about 2D animation projects and have a deeper and logical understanding of how to create 2D animation [32].

Many studies have examined the use of interactive and flash-based media to enhance student learning outcomes [28], [33], [34]. However, no one has reviewed the effectiveness of the use of interactive multimedia on $\mathrm{PjBL}$ for making $2 \mathrm{D}$ animations. Therefore, the results of this study can be an alternative for lecturers to enhance learning outcomes for Information Technology Education students who are accustomed to being given a project in the learning process. Lecturers have many examples and exercises contained in interactive multimedia to teach 2D animation making material, so students can see examples of it and have time to practice it.

\section{Conclusion}

This study concluded that: 1) The development steps produce interactive multimedia 2) Validation by material and media experts showed that the interactive multimedia is very good and feasible to use in the learning process Information Technology Education, and 3) The application showed that the interactive multimedia on PjBL is effective to enhance the ability to make a $2 \mathrm{D}$ animation.

These findings can be used by educators to innovate the teaching and learning process. 


\section{Acknowledgement}

The authors express gratitude to the Education Fund Management Institution (LPDP) from the Ministry of Finance of Indonesia for the information, policy, and funding of this research.

\section{References}

[1] M. F. Amir, F. N. Hasanah, and H. Musthofa, "Interactive Multimedia Based Mathematics Problem Solving to Develop Student s' Reasoning," Int. J. Eng. Technol., vol. 7, no. 2.14, pp. 272-276, 2018.

[2] D. Holmes, Communication theory: Media, technology and society. United Kingdom: SAGE Publications Ltd, 2005.

[3] A. S. Ahmar and A. Rahman, "Development of teaching material using an Android," Glob. J. Eng. Educ., vol. 19, no. 1, pp. 72-76, 2017.

[4] T.-K. Neo, M. Neo, W.-J. Kwok, Y.-J. Tan, C.-H. Lai, and C. E. Zarina, "MICE 2.0: Designing multimedia content to foster active learning in a Malaysian classroom," Australas. J. Educ. Technol., vol. 28, no. 5, pp. 857-880, 2012. https://doi.org/10.14742/ajet.821

[5] M. Sabin, Information Technology Curricula 2017: Curriculum Guidelines for Baccalaureate Degree Programs in Information Technology. 2017. https://doi.org/10.1145/3173161

[6] C. F. Wu and M. C. Chiang, "Effectiveness of applying 2D static depictions and 3D animations to orthographic views learning in graphical course," Comput. Educ., vol. 63, pp. 28-42, 2013. https://doi.org/10.1016/j.compedu.2012.11.012

[7] D. Richards and M. Taylor, A Comparison of learning gains when using a 2D simulation tool versus a 3D virtual world: An experiment to find the right representation involving the Marginal Value Theorem, vol. 86. Elsevier Ltd, 2015. https://doi.org/10.1016/j.compedu. 2015.03.009

[8] E. Ozcelik and C. Acarturk, "Reducing the spatial distance between printed and online information sources by means of mobile technology enhances learning: Using 2D barcodes," Comput. Educ., vol. 57, no. 3, pp. 2077-2085, 2011. https://doi.org/10.1016/j.compedu.20 $\underline{11.05 .019}$

[9] N. F. Jumaat and Z. Tasir, "Integrating Project Based Learning Environment into the Design and Development of Mobile Apps for Learning 2D-Animation," Procedia - Soc. Behav. Sci., vol. 103, pp. 526-533, 2013. https://doi.org/10.1016/j.sbspro.2013.10.369

[10] A. Ana and L. Nurlaela, "Development model of patisserie project-based learning," J. Tech. Educ. Train., vol. 4, no. 2, pp. 30-44, 2012.

[11] I. Bilgin, E. Şenocak, and M. Sözbilir, "The effects of problem-based learning instruction on university students' performance of conceptual and quantitative problems in gas concepts,” EURASIA J. Math. Sci. Technol. Educ., vol. 5, no. 2, pp. 153-164, 2009. https:// doi.org/10.12973/ejmste/75267

[12] H. E. Rudyanto, A. Ghufron, and Hartono, "Use of integrated mobile application with realistic mathematics education: A study to develop elementary students' creative thinking ability,” Int. J. Interact. Mob. Technol., vol. 13, no. 10, pp. 19-27, 2019. https://doi.org/10. $\underline{\text { 3991/ijim.v13i10.11598 }}$

[13] D. H. J. M. Dolmans and H. G. Schmidt, "What do we know about cognitive and motivational effects of small group tutorials in problem-based learning?," Adv. Heal. Sci. Educ., vol. 11, p. 321, 2006. https://doi.org/10.1007/s10459-006-9012-8 
[14] N. Jalinus, S. Syahril, and R. A. Nabawi, "A comparison of the problem-solving skills of students in PjBL versus CPjBL model: An experimental study,” J. Tech. Educ. Train., vol. 11, no. 1, pp. 36-43, 2019.

[15] V. B. Gómez-Pablos, M. M. del Pozo, and A. G.-V. Muñoz-Repiso, "Project-based learning (PBL) through the incorporation of digital technologies: An evaluation based on the experience of serving teachers," Comput. Human Behav., vol. 68, pp. 501-512, 2017. https $: / /$ doi.org/10.1016/j.chb.2016.11.056

[16] M. F. Amir, N. Ariyanti, N. Anwar, E. Valentino, and D. S. N. Afifah, "Augmented Reality Mobile Learning System : Study to Improve PSTs' Understanding of Mathematical Development," Int. J. Interact. Mob. Technol., vol. 14, no. 9, pp. 239-247, 2020. https://doi. org/10.3991/ijim.v14i09.12909

[17] Y.-M. Shiue and Y.-C. Hsu, "Understanding Factors that Affecting Continuance Usage Intention of Game-Based Learning in the Context of Collaborative Learning," EURASIA J. Math. Sci. Technol. Educ., vol. 13, no. 10, pp. 6445-6455, 2017. https://doi.org/10.12973/ ejmste/77949

[18] H. E. Rudyanto, Marsigit, M. N. Wangid, and S. Gembong, "The use of bring your own device-based learning to measure student algebraic thinking ability," Int. J. Emerg. Technol. Learn., vol. 14, no. 23, pp. 233-241, 2019. https://doi.org/10.3991/ijet.v14i23.11050

[19] M. A. Albanese and S. Mitchell, "Problem-based learning: A review of literature on its outcomes and implementation issues," Acad. Med., vol. 68, no. 1, pp. 52-81, 1993.

[20] S. Thiagarajan, Instructional development for training teachers of exceptional children: A sourcebook. 1974.

[21] D. T. Campbell and J. C. Stanley, Experimental and quasi-experimental designs for research. Ravenio Books, 2015.

[22] W. Ardhana, "Kesanggupan Berpikir Formal ala Piaget dan Kemajuan Belajar di Sekolah (Piaget's Formal Thinking Skills and School Learning Progress)," 1983.

[23] Sugiyono, Metode Penelitian Kuantitatif, kualitatif dan R \& D. Bandung: Alfabeta, 2013.

[24] K. L. Narayana, Machine drawing, 3rd Editio. New Age International, 2009.

[25] A. Białkiewicz, "Propaedeutics of teaching drawing to architects," Glob. J. Eng. Educ., vol. 21, no. 2, pp. 115-120, 2019.

[26] K. M. Slunt and L. C. Giancarlo, "Student-centered learning: A comparison of two different methods of instruction," J. Chem. Educ., vol. 81, no. 7, p. 985, 2004. https://doi.org/10. $\underline{1021 / \mathrm{ed} 081 \mathrm{p} 985}$

[27] B. DePorter, M. Hernacki, and A. Abdurrahman, Quantum learning: membiasakan belajar nyaman dan menyenangkan. Jakarta: Penerbit Kaifa, 1999.

[28] F. Özdamli, "The experiences of teacher candidates in developing instructional multimedia materials in project based learning," Procedia - Soc. Behav. Sci., vol. 15, pp. 3810-3820, 2011. https://doi.org/10.1016/j.sbspro.2011.04.378

[29] P. Chatwattana, "Concepts of an interactive adaptive learning system architecture design in an active learning environment through a cloud learning ecosystem," Glob. J. Eng. Educ., vol. 20, no. 2, pp. 181-189, 2018.

[30] M. Simkins, K. Cole, and F. Tavalin, Increasing student learning through multimedia projects. ASCD, 2002.

[31] I. Mcalpine and R. Clements, "Problem based learning in the design of a multimedia project," Austaralian J. Educ. Technol., vol. 17, no. 2, pp. 115-130, 2001.

[32] M. Neo, K. T. K. Neo, H. Y. J. Tan, Joyce, W. J. Kwok, and C. H. Lai, "Problem-solving in a Multimedia Learning Environment: The MILE @ HOME Project," in International Educational Technology Conference, 2012, vol. 64, pp. 26-33. https://doi.org/10.1016/j. sbspro.2012.11.004 
[33] R. R. García, J. S. Quirós, R. G. Santos, S. M. González, and S. M. Fernanz, "Interactive multimedia animation with Macromedia Flash in Descriptive Geometry teaching," Comput. Educ., vol. 49, no. 3, pp. 615-639, 2007. https://doi.org/10.1016/j.compedu.2005.11.0 $\underline{05}$

[34] W. Lisda, M. A. Rahman, and H. Atmowardoyo, "The Use of Macromedia Flash Animation to Enhance Students' English Writing Skill at the Seventh Grade of SMP Yapis 1 Fakfak-West Papua," ELT Worldw., vol. 2, no. 2, pp. 45-61, 2015.

\section{$7 \quad$ Authors}

Rahmania Sri Untari is a postgraduate student at the Universitas Negeri Malang, East Java, Indonesia. Currently he also teaches at the Information Technology Education Universitas Muhammadiyah Sidoarjo, East Java, Indonesia. His research interests are project-based learning, instructional media development, and vocational education.

Waras Kamdi is a Professor at the Faculty of Engineering, Universitas Negeri Malang, East Java, Indonesia. His research interests include vocational education, project-based learning, education technology, and teaching and learning in higher education.

Ahmad Dardiri is a Lecturer at Universitas Negeri Malang, East Java, Indonesia. His research interests include vocational education, career development, and entrepreneurship.

Syamsul Hadi is a Head of postgraduate primary education at the Universitas Negeri Malang, East Java, Indonesia. His research interests include education management, leadership, and vocational education.

Didik Nurhadi is an Assistant Professor of the Engineering Faculty at the Universitas Negeri Malang, Indonesia. He received his Master degree from the Post Graduate of Universitas Negeri Malang and his PhD from the Doctoral of Technological and Vocational Education at National Yunlin University of Science and Technology in Taiwan. His research focuses on human resources, risk management, vocational teacher education, students' internship, and teaching and learning in higher education.

Article submitted 2020-06-29. Resubmitted --. Final acceptance 2020-07-01. Final version published as submitted by the authors. 